"Role of dividend policy determinants in multinational and domestic companies, evidence from Iran"

$\begin{array}{ll}\text { FUThORS } & \text { Farhad Fatemian } \\ \text { Mohammad Hooshyarzadeh }\end{array}$

Farhad Fatemian and Mohammad Hooshyarzadeh (2016). Role of dividend

ARTICLE INFO policy determinants in multinational and domestic companies, evidence from Iran. Problems and Perspectives in Management, 14(3-si), 332-340.

doi:10.21511/ppm.14(3-si).2016.05

DOI

http://dx.doi.org/10.21511/ppm.14(3-si).2016.05

RELEASED ON

Thursday, 15 September 2016

JOURNAL

"Problems and Perspectives in Management"

FOUNDER

LLC "Consulting Publishing Company "Business Perspectives"

NUMBER OF REFERENCES

0
NUMBER OF FIGURES

0

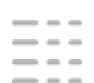

NUMBER OF TABLES

0

(C) The author(s) 2023. This publication is an open access article. 
Farhad Fatemian (Iran), Mohammad Hooshyarzadeh (Iran)

\title{
Role of dividend policy determinants in multinational and domestic companies, evidence from Iran
}

\begin{abstract}
In this paper, along with introducing determinants affecting decision making relevant to dividend policy, the impact of these factors on companies which merely sell their products domestically is compared with their impact on companies which, in addition to domestic sales, have exports as well. In this regard, 712 companies were tested during the years 2008 to 2013.

In this study, the ratio of dividend per share to earnings per share (DPS/EPS) was used as a dividend policy index; for expressing the significant difference in dividend policy of multinational and domestic companies, $t$ and "Mann Whitney" tests were applied. For stating the determinants in dividend policy, the variables systematic risk, profitability, free cash flow, sales growth, firm size and leverage were used. For the analysis and interpretation of data, a multivariate linear regression model was implemented as panel data. Research findings demonstrate the existence of significant difference in dividend policy of multinational and domestic companies such that the multinational companies shared more profit compared with their domestic counterparts. Whereas only leverage and profitability were among the determinants in the domestic companies, for multinational companies, in addition to these variables, the variables of free cash flows and sales growth were also among significant factors. Furthermore, the impact of Beta variables and the firm size were not found significant on dividend policy of domestic and multinational companies.
\end{abstract}

Keywords: dividend policy, long term debt, multinational companies (MCs), domestic companies (DCs).

JEL Classification: G32, G35, H63, F23.

\section{Introduction}

Decisions regarding financing, investing funds and dividend are considered three main areas of decision making in finance. Thus, researchers in the field of finance are very interested in studies related to these three areas. The development of the above concepts is influenced by the economic, social, political and behavioral factors at the level of governments and individuals. The subject of dividend has numerous angles. From the perspective of minority investors, the distribution of profits is different from that of majority investors (strategic). Difference of opinion between investors and managers is also another issue. Thus, despite numerous investigations with the subject of dividend, the puzzle of mutual relations among interest groups such that brings maximum satisfaction is not yet possible for the foregoing reasons. Some people believe that if the profit is not distributed, because they invest in future operations, it will not affect the company's stock price. Thus they believe that no negative reaction has been seen from investors for the lack of dividend policy (Miller and Modigliani, 1958).

Some people believe that companies reveal their capabilities to investors with profit distribution. Investors also, due to observing appropriate feedback from previous investment, provide grounds for the maintenance and growth of stock market price. Thus, stock price is in harmony with this policy. Another

(c) Farhad Fatemian, Mohammad Hooshyarzadeh, 2016

Farhad Fatemian, Ph.D. Candidate in finance, Department of Finance, Faculty of Management \& Social Science, North Tehran Branch, Islamic Azad University, Tehran, Iran.

Mohammad Hooshyarzadeh, Ph.D. Candidate in finance, Department of Finance, Faculty of Management \& Social Science, North Tehran Branch, Islamic Azad University, Tehran, Iran. group of researchers state that with profit distribution, the excess cash sector withdrew from management controls thereby averting their inefficient behaviors.

Since dividend was addressed in scientific research discussions, very few researches have tested factors affecting dividend policy and various dividend payout methods by multinational and domestic companies. These variations and differences are still likely to be discussed and contemplated because multinational companies (MCs) and domestic companies (DCs) are significantly associated with risk, operational activities and financing activities are different, which affect dividend payouts. So that multinational companies, compared with domestic firms, are more at risk (political risk, foreign exchange, exchange rate fluctuations, various rules, etc.) and, in their activities, are relatively diverse (geographical and industrial dispersion). On the other hand, multinational companies have an easier access to international financial markets for financing, and these factors affect their dividend policy (Akhtar, 2007).

The impact of multinationality on dividend policy is still one of the challenging debates in the international financial arena. Numerous researchers have attempted its interpretation from various aspects. And yet, general consensus does not exist regarding the effectiveness of companies' presence in the international arena on dividend policy and that which variables are factors determining the dividend policy of multinational and domestic companies.

\section{Theoretical framework}

Miller and Modigliani (1958) stated that, under certain conditions and hypotheses, dividend has no effect on 
stock prices; subsequently, other researchers declared that these hypotheses do not exist in the real world and when the market does not have the efficiency, sharing the profit will be influential on the company's value. Following the acquisition of multiple outcomes, the tax preference theory was announced (Brennan, 1970 and William, 1985). This theory asserts that dividends are included in direct tax and dividends and, until profit is not distributed to shareholders, tax performance remains pending. Therefore, investors prefer that, instead of dividing the share, the profit be retained within the company. Thus, investors seek companies which divide less profit. While the theory of signaling which was introduced in the 90s, says that companies use dividends as a means to signal to investors about their performance. In this theory, the ability to divide the profit, as a positive rating, affects the stock market price (Aharony and Swary, 1980).

Based on the theory of transaction costs, the high cost of financing from foreign sources induces companies to pay fewer dividends (Holder et al., 1998). Other proposed theories about dividend policy which were introduced in the 1980s, view dividend payout as related to agency costs arising from supervision/management costs of the company to avoid inefficient behavior (La Porta et al., 2000). More dividend payouts will reduce free cash flows such that would induce management to perform foreign financing and, thus, the company's management become responsible towards the suppliers of capital and agency costs will decrease (Holder et al., 1998 and Easterbrook, 1984). According to the agency model of Jensen and Meckling (1976), if there is conflict of interests between managers and shareholders, dividends are used as agency cost control tools. Consequently, the agency cost theory predicts a positive relationship between free cash flows and dividend payout.

1.1. Risk. Many researchers, in the previous studies, have used the beta variable as a systematic risk criterion to measure stock's volatility in relation with the market (Dickens, 2000). Accordingly, it is expected that riskier companies should have higher cash flow volatility than less risky companies. As a result, financial suppliers of these companies force them to divide less profit between shareholders. Moreover, based on Rozeff's theories (1982), riskier companies pay fewer dividends and this determines the negative relationship between dividends and bankruptcy costs. Mohd and others (1995) also reported an inverse relationship between risks and dividends.

Domestic companies' area of activity is only in one country, while multinational companies act in more than one country and are more vastly dispersed. Because different countries have different economic milieu and are less dependent on one another, multinational companies are provided with greater possibility for diversification. As a result of this advantage, changes in cash flows become less and the insolvency risk and their expected bankruptcy costs are reduced. Therefore, multinational companies pay higher dividends compared with domestic companies.

In this research, as in Rozeff (1982) and Manos (2002), beta was used as risk criterion.

1.2. Profitability. In previous studies, the existence of positive and negative relationship between the company's profitability and dividend was stated (Jensen et al., 1992 and Fama and French, 2001). Based on Ross's messaging hypothesis (1977), companies with high profitability pay higher dividends as signs of higher credit. Nevertheless, Myers believes that companies prefer increasing their capital, first, through the accumulation of profit, then, through debt and, finally, through share distribution and demonstrated that companies with higher future profitability for using investment opportunities pay fewer dividends. In another research, Fama and French (2001) concluded that each company's profitability has a direct relationship with their dividends. DeAngelo and others (2004) confirmed that the existence of high dividends is a consequence of enhancement in the company's net profit.

Compared with domestic companies, multinational companies, due to greater access to sources of profit and also more opportunities to acquire the desired commercial success, have better opportunities to earn more profit (Akhtar, 2008). Consequently, multinational companies will most probably be more profitable than domestic companies and will have higher capability in dividend payout.

Following the Aggarwal and Aung Kyaw (2010), in this study, the rate of return on assets (ROA) was used as a criterion of profitability.

1.3. Free cash flows. Jensen (1986) stated that, when free cash flows increase, conflicts of interest between managers and shareholders increase as well, which, then, leads to increase of agency costs and reduction of organization efficiency. While shareholders expect that managers act in order to maximize the company's value, managers may tend to use profit for the interests and objectives of their own. To reduce this conflict, higher dividend payout is recommended. Previous studies have indicated that companies with high cash flows divide more profit since it leads to reduction of free cash flows and, subsequently, reduction of agency cost (La Porta et al., 2000). According to results of the mentioned studies, a positive relationship is predicted between free cash flows and dividend payout. 
Due to the activities of multinational companies in various countries, these companies' agency costs increase (Lee and Ki-Wook, 1988). Monitoring the activities of these companies is, due to geographical dispersion and cultural differences, associated with higher monitoring costs. On the other hand, because of the different situations of international managers in international markets, the possibility of monitoring their works will be more complicated. Thus, the risk of forecasting cash flows from the activities of multinational corporations will increase. Accordingly, it is expected that multinational companies have higher agency costs compared with domestic companies and, therefore, pay lower dividends.

1.4. Firm size. Fama and French (2001) stated that larger companies distribute more net profit as dividends among the shareholders compared with smaller companies. There are many other studies that tested the impact of firm size on the company's dividend policy. Results of researches by Lloyd (1958) and Vogt (1994) demonstrated that firm size has a direct relationship with the company's dividend. Sawicki (2005) also emphasized the existence of a positive correlation between firm size and the company's dividend. He stated that, due to the dispersion of ownership in large corporations, heterogeneous information increase, which causes reduction of the monitoring power of shareholders on managers' activities. Higher dividend payouts could solve this problem. Because higher dividend payouts would lead to an enhanced need for foreign financing and the need for foreign financing, in turn, leads to an increase in supervision of larger corporations' activities, due to the existence of creditors.

Some scholars expressed positive relationship between firm size and dividend payout, in terms of operating costs. Holder et al. (1998) revealed that larger companies have easier access to financial markets and can obtain loan through debt with lower cost. Therefore, they will be able to share more profits between shareholders.

Generally, it is expected that multinational companies are larger in size than domestic firms, thus, more able to pay dividends.

1.5. Financial debt. There are numerous studies which demonstrate that the level of corporate debt is negatively associated with dividend policy. These researches infer that companies with more debt attempt to keep cash flows within the company in order to cover the costs of taxes and interest (Faccio and Lang, 2002 and Aggarwal and Aung Kyaw, 2010). Rozeff (1982) indicated that companies with higher risk pay lower dividends.

Mollah and others (2002) tested data for developing countries and demonstrated that there is a direct relationship between the level of debt and operating costs. Therefore, companies which maintain more debt in their capital structure, have higher trading costs and are in a weak financial situation to be able to pay more dividends.

Previous empirical research on the factors affecting capital structure of multinational companies indicated that multinational companies have lower debt levels compared with domestic firms. Therefore, it is expected that, if multinational companies keep other factors constant, they will pay lower dividends, considering the negative correlation between the level of debt and dividend payout.

1.6. Sales growth. From one perspective, companies are, first, inclined to utilize internal resources to finance their projects. Therefore, companies with higher growth reduce their dividends and keep profit within the company. Companies with more future growth, require more liquidity, thus, share less profit as dividends among shareholders (La Porta, 2000). Therefore, a negative relationship is assigned between growth opportunities and profitability and dividend payout. On the other hand, the results of several studies revealed a direct relation between growth and dividend. The results of those researches indicate that companies are seriously avoiding reduction of dividend payouts (Brav et al., 2005). It is expected that multinational companies should take advantage of economic opportunities and experience further growth. Therefore, we expect a significant impact of growth opportunities on dividend policy.

\section{Research methodology}

2.1. Research hypotheses. Main hypothesis: a significant difference exists between dividend policy of multinational companies and domestic companies.

Subsidiary hypotheses for domestic and multinational companies:

Hypothesis 1: the impact of systematic risk on dividend payout ratio is negative and significant.

Hypothesis 2: the impact of profitability on dividend payout ratio is positive and significant.

Hypothesis 3: the impact of free cash flows on dividend payout ratio is significant.

Hypothesis 4: the impact of firm size on dividend payout ratio is positive and significant.

Hypothesis 5: the impact of financial leverage on dividend payout ratio is negative and significant.

Hypothesis 6: the impact of sales growth on dividend payout ratio is significant.

2.2. Research method. The present study aims to investigate into the problem of whether the 
determinants have any significant impact on dividend policy of the DC and MC companies listed in Tehran Stock Exchange? This research is a descriptivecorrelation study and, based on the method of collecting data, is post-event. In the study, for the comparison of multinational and domestic companies' dividend policy, one sample t-tests and Mann-Whitney tests were used and multivariate linear regression model was applied with the paneled data approach in order to examine the relevant hypotheses.

2.3. Population and sample. The population includes all listed companies in Tehran Stock Exchange in the period 2008-2013 during which their information was available and consists of the following conditions. 1 - Information is available during the research period. 2 - Fiscal period of companies lead to end of Isfand Iranian calendar each year. 3 - No change occurs in the financial period from 2008 to 2013. 4 - Companies have no trading interval exceeding 6 months from 2008 to 2014. 5 - They are not part of holding companies, investment, banks, insurance, financial institutions and financial intermediation. Applying the above constraints, 712 companies were selected by using screening method.
2.4. Model and variables. The general model of research was clarified in the form of a multivariate regression model as follows.

Model no 1:

$$
\begin{aligned}
& D P R=b_{0}+b_{1} \text { Beta }+b_{2} R O A+b_{3} \text { Sales } G R+ \\
& +b_{4} \text { FreeCFLs }+b_{5} \text { Lsize }+b_{6} \text { Leverage }+ \\
& +b_{7} \text { Fsale or } M
\end{aligned}
$$

The research variables, including two groups of dependent variable and independent variables, are as follows:

\section{A) Dependent variable}

Dependent variable, in this research, is dividend policy index, which is obtained from dividing dividends per share by earnings per share.

\section{B) Independent Variables}

In this study, seven features of a company consisting of systematic risk, profitability, sales growth, firm size, financial leverage, foreign sales and free cash flows have been considered as independent variables.

Table 1. Variables definition

\begin{tabular}{|l|l|l|}
\hline \multicolumn{1}{|c|}{ Symbol } & \multicolumn{1}{c|}{ Definition } & Unit \\
\hline DPR & Dividend per share compared to earnings per share & Ratio \\
\hline LTD & Long-term debt divided by the sum of long-term debt and corporate market value & Ratio \\
\hline Fsales & Foreign sales divided by total sales & Ratio \\
\hline M & Dummy variable for the multinational (If you have more than 2\% of exports 1 and otherwise 0) & Nominal \\
\hline Beta & Systemic risk criterion & Ratio \\
\hline ROA & Net profit (loss) divided by total assets & Ratio \\
\hline SalesGR & Geometric mean of company's 3-year sales growth rate & Ratio \\
\hline FreeCFL & Cash flows from operating activities minus dividend overpay minus capital expenditures divided by total assets & Ratio \\
\hline Lsize & Natural logarithm of total assets & Differential \\
\hline
\end{tabular}

\section{Results of hypotheses test}

\begin{tabular}{|c|c|c|c|c|c|c|c|c|}
\hline Variables & DPR & ROA & Lsize & Beta & SalesGR & FreeCFL & LTD & Fsales \\
\hline \multicolumn{9}{|l|}{ Total firms } \\
\hline Number & 712 & 712 & 712 & 712 & 712 & 712 & 712 & 712 \\
\hline Mean & 61.321 & 12.798 & 12.953 & 0.406 & 0.24 & -0.181 & 0.135 & 0.086 \\
\hline S.D & 44.589 & 12.474 & 1.312 & 1.595 & 1.441 & 3.222 & 0.152 & 0.175 \\
\hline Min & 0 & -31.272 & 9.778 & -5.9 & -0.552 & -67.955 & 0 & 0 \\
\hline Max & 553.349 & 62.74 & 18.195 & 19.32 & 38.263 & 0.732 & 0.678 & 1 \\
\hline \multicolumn{9}{|c|}{ Multinational companies } \\
\hline Number & 356 & 356 & 356 & 356 & 356 & 356 & 356 & 356 \\
\hline Mean & 64.626 & 14.859 & 13.218 & 0.471 & 0.289 & -0.007 & 0.12 & 0.172 \\
\hline S.D & 43.561 & 14.074 & 1.27 & 1.575 & 2.025 & 0.159 & 0.123 & 0.215 \\
\hline Minimum & 0 & -31.272 & 9.797 & -5.9 & -0.351 & -0.66 & 0 & 0.02 \\
\hline Maximum & 485.386 & 62.74 & 18.195 & 19.32 & 38.263 & 0.732 & 0.678 & 1 \\
\hline \multicolumn{9}{|c|}{ Domestic companies } \\
\hline Number & 356 & 356 & 356 & 356 & 356 & 356 & 356 & 356 \\
\hline Mean & 58.016 & 10.732 & 12.688 & 0.341 & 0.191 & -0.355 & 150 & 0 \\
\hline
\end{tabular}

\subsection{Descriptive statistics.}

Table 2. Descriptive statistics for all data 
Table 2 (cont.). Descriptive statistics for all data

\begin{tabular}{|l|c|c|c|c|c|c|c|c|}
\hline Variables & DPR & ROA & Lsize & Beta & SalesGR & FreeCFL & LTD & Fsales \\
\hline S.D & 45.414 & 10.252 & 1.301 & 1.616 & 0.231 & 4.55 & 0.176 & 0 \\
\hline Min & 0 & -19.765 & 9.778 & -5.037 & -0.552 & -67.955 & 0 & 0 \\
\hline Max & 553.349 & 44.944 & 16.437 & 16.901 & 1.399 & 0.648 & 0.947 & 0 \\
\hline
\end{tabular}

3.2. Main hypothesis: There is a significant difference between dividend policy of multinational and domestic companies.

In this hypothesis, mean difference of dividend ratio in multinational and domestic companies were tested, as the dividend policy index, using a univariate t-tests and Mann-Whitney test. According to table 3, significant level, both for t-test and Mann-Whitney test, is below 5 percent and the main hypothesis is confirmed in significant level 95 percent, i.e. there is a significant difference between dividend policy of multinational and domestic companies such that multinational companies pay significantly higher dividends compared with domestic firms.

Table 3. Results of t-test and Mann-Whitney tests in main hypothesis

\begin{tabular}{|l|c|c|c|c|c|}
\hline $\begin{array}{c}\text { Dependent } \\
\text { variable: }\end{array}$ & $\begin{array}{c}\text { Significant } \\
\text { level }\end{array}$ & $\mathrm{t}$ & $\begin{array}{c}\text { Significant } \\
\text { level }\end{array}$ & $\begin{array}{c}\text { Mann- } \\
\text { Whitney }\end{array}$ & $\begin{array}{c}\text { Hypothesis } \\
\text { result }\end{array}$ \\
\hline DPR & 0.048 & -1.982 & 0.008 & 5616 & Verification \\
\hline
\end{tabular}

For further explanation, the results of t-test and Mann-Whitney tests for other independent variables of the model are presented in the table below.

Table 4. Results of $t$ and Mann-Whitney tests

\begin{tabular}{|l|c|c|c|c|c|c|}
\hline & Beta & LTD & ROA & Lsize & SalesGR & FreeCFL \\
\hline Multinational companies (mean) & 0.471 & 0.12 & 14.859 & 13.218 & 0.289 & -0.007 \\
\hline Domestic companies (mean) & 0.341 & 0.15 & 10.737 & 12.688 & 0.191 & -0.355 \\
\hline t-test & -1.09 & 2.657 & -4.467 & -5.503 & -0.907 & -1.442 \\
\hline Significant level & 0.276 & 0.008 & 0 & 0 & 0.365 & 0.15 \\
\hline Mann-Whitney & -2.465 & -1.541 & -4.294 & -6.02 & -1.245 & -0.624 \\
\hline Significant level & 0.014 & 0.123 & 0 & 0 & 0.213 & 0.533 \\
\hline
\end{tabular}

3.3. Subsidiary hypotheses. Prior to hypotheses testing, it is compulsory to ensure the establishment of some initial rules of regression model. First, in order to investigate the normality of dividend ratio variable, Kolmogorov-Smirnov test was used. As observed in Table 5, significant level after normalization is more than 0.05 . Therefore, it can be said that this variable is normal.

Table 5. Results of the Kolmogorov-Smirnov test

\begin{tabular}{|c|l|c|c|c|}
\hline $\begin{array}{c}\text { Dependent } \\
\text { variable }\end{array}$ & \multicolumn{1}{|c|}{$\begin{array}{c}\text { Type of } \\
\text { companies }\end{array}$} & Number & K-S & Sig. \\
\hline \multirow{3}{*}{ DPR } & Dc & 356 & 1.105 & 0.109 \\
\cline { 2 - 5 } & Mc & 356 & 0.822 & 0.223 \\
\cline { 2 - 5 } & Total & 712 & 1.054 & 0.121 \\
\hline
\end{tabular}

Afterwards, total significance of regression was tested and the results are demonstrated in Table 6.

Table 6. Total significance of regression

\begin{tabular}{|c|l|c|c|c|c|c|}
\hline DPR & \multicolumn{1}{|c|}{ Model } & $\begin{array}{c}\text { The sum } \\
\text { of } \\
\text { squares }\end{array}$ & $\begin{array}{c}\text { Degrees } \\
\text { of } \\
\text { freedom }\end{array}$ & $\begin{array}{c}\text { Mean } \\
\text { square }\end{array}$ & F ratio & \multirow{2}{*}{ Sig. } \\
\hline \multirow{3}{*}{ MC } & Regression & 53.549 & 7 & 7.65 & 9.333 & \multirow{2}{*}{0} \\
\cline { 2 - 6 } & Residual & 285.257 & 348 & 0.82 & & \\
\cline { 2 - 6 } & Sum & 338.806 & 355 & & & \\
\hline \multirow{3}{*}{ DC } & Regression & 33.047 & 6 & 5.508 & \multirow{3}{*}{0.735} & \multirow{2}{*}{0} \\
\cline { 2 - 6 } & Residual & 335.199 & 349 & 0.96 & & \\
\cline { 2 - 6 } & Sum & 368.246 & 355 & & & \\
\hline
\end{tabular}

As seen, on the one hand, the obtained $\mathrm{F}$ ratios for multinational and domestic companies were, respectively, 9.333 and 5.375, which is more than the table value $\mathrm{F}_{0.05,6.349}=2.10$ for both groups. On the other hand, significant level of both models is less than 5 percent, which is indicative of total significance of regression model. Given that the value of DurbinWatson statistic is more than 1.5 for both models, it can be claimed that there is no multicollinearity problem. Moreover, according to the coefficient of determination of multinational companies' model, it can be argued that this regression alone justifies $14.1 \%$ of changes and, furthermore, according to the coefficient of determination of domestic companies' model, it can be stated that, approximately, $8 \%$ of the changes associated with dividends are described by the said variables.

Table 7. Regression results

\begin{tabular}{|l|c|c|c|c|}
\hline \multirow{2}{*}{ Independent variables } & \multicolumn{2}{|c|}{ MC } & \multicolumn{2}{c|}{ DC } \\
\cline { 2 - 5 } & Coefficient & Sig. & Coefficient & Sig. \\
\hline Constant & -0.849 & 0.098 & -0.564 & 0.28 \\
\hline Beta & -0.037 & 0.242 & -0.042 & 0.203 \\
\hline ROA & 0.013 & 0.001 & 0.012 & 0.042 \\
\hline Sales GR & 0.112 & 0 & 0.307 & 0.221 \\
\hline Free CFL & -1.018 & 0.001 & -0.004 & 0.701 \\
\hline Lsize & 0.064 & 0.105 & 0.038 & 0.37 \\
\hline LTD & -0.866 & 0.055 & -1.11 & 0.001 \\
\hline MCs & $0.141=$ Adjusted R2 & DW $=2.086$ \\
\hline MCs & $0.074=$ Adjusted R2 & DW $=1.909$ \\
\hline
\end{tabular}


The results in Table 7 attempt to demonstrate effective factors, which describe the differences between dividend payout ratio in DCs and MCs.

3.3.1. First subsidiary hypothesis: the impact of systematic risk on dividend payout ratio is negative and significant.

According to Table 4, significant level resulting from $t$ and Mann Whitney tests are indicative of lack of difference in mean systematic risk of multinational and domestic companies $(\mathrm{sig}=0.276)$. According to Table 7 , the impact of systematic risk (beta) on dividend policy of multinational and domestic companies is negative and was not significant for any of the two groups.

3.3.2. Second subsidiary hypothesis: the impact of profitability on dividend payout ratio is positive and significant.

The effect of profitability on dividend policy is positive and significant, which is reported as 0.013 and 0.012 for MCs and DCs, respectively. Namely that in case of an increase in net profit for corporate financial period, profit distribution will also increase. On the other hand, according to Table 4, in error level 1 percent, there is a significant difference between profitability of multinational and domestic companies such that multinational companies have higher profitability (average 14.859 percent) compared with domestic companies (average 10.737 percent). Based on the two provided analyses above, it is evident that not only does profitability have a positive and significant impact on dividend policy, but also contains even greater impact on MCs compared with that DCs, due to multinational companies' higher level of profitability.

3.3.3. Third subsidiary hypothesis: the impact of free cash flows on dividend payout ratio is significant.

Although, based on the analysis set forth in Table 4, at the confidence level of $95 \%$, there is no significant difference in the mean free cash flow of multinational and domestic companies, still, the impact of free cash flows presence in multinational companies is negative $(-1,018)$ and significant in error level of 1 percent. Whereas, for domestic companies, despite the negative impact of free cash flows (-0.004), this impact was not significant.

3.3.4. Fourth subsidiary hypothesis: the impact of firm size on dividend payout ratio is positive and significant.

The size of multinational and domestic companies is, respectively, 13.218 and 12.688 , which has a significant difference in the significant level of 99 percent. However, based on regression model results, although the impact of size on dividend was positive, this effect was not significant for any of MCs and DCs.

3.3.5. Fifth subsidiary hypothesis: the impact of financial leverage on dividend payout ratio is negative and significant.

According to Table 4, significant level resulting from t-test is indicative of the presence of difference in mean long-term debt of MCs and DCs at the significant level of 99 percent so that MCs use lower long-term debt.

According to Table 7, the impact of long-term debt on dividend policy of multinational and domestic companies is inverse and significant. The impact of long-term debt on multinational and domestic companies is, respectively, -0.866 and -1.11 . These amounts were verified with the significant level of 90 percent in MCs and 99 percent in DCS. According to the two presented analyses above, on the one hand, in addition to DCs' having higher long-term debt level compared with MCs (0.150 and 0.120 , respectively), the negative impact of long-term debt on dividend policy of DCs is also more severe.

3.3.6. Sixth subsidiary hypothesis: the impact of sales growth on dividend payout ratio is significant.

According to Table 4, significant level of mean sales growth difference in MCs and DCs is 0.213. This value is more than the acceptable error level of 5 percent. Consequently, the significant difference in sales growth of MCs and DCs was not observed.

The impact of sales growth in MCs on dividend policy was found positive (0.112) and significant (at the error level of 1 percent). In fact, with the significant level of 99 percent, the impact of sales growth on dividend policy of MCs can be verified. While the impact of sales growth on dividend policy of DCs is positive, it was not found significant.

\section{Conclusion}

The results of hypothesis test, using information related to MCs and DCs active in Tehran Stock Exchange, during the period 2008-2013, indicated that, in addition to significant difference between dividend ratio of MCs and DCs, there is a significant difference between the determinants affecting dividend policy of these two groups.

MCs, compared with DCs, significantly, distributed more profits among their shareholders as dividends. These results were consistent with the results obtained by Aggarwal and Aung Kyaw (2010) and in contrast with the findings of Shami Akhtar (2009).

According to the results of Manos and Rozeff (1986), as the volatility of cash flow, yields and stock prices in the market rises, a great number of shareholders will, 
increasingly, become concerned. Ordinarily, in inefficient capital markets, the existence of this phenomenon intensifies the concerns of shareholders. Since, they will not find the possibility of effective reaction at appropriate times. Consequently, risk and dividend policy have an inverse relationship. The results obtained from the first hypothesis test are indicative of the increasing concerns of Iranian shareholders in stock trading of companies active in Tehran Stock Exchange. They prefer increasing the distribution of financial resources resulted from dividend payout at times of concerns arising from fluctuations. This impact is also stronger in MCs compared with DCs. With respect to the type of impact, significant difference has not occurred between them.

According to political hypothesis, larger corporations, due to being under greater control, for the reduction of pressures from government and other beneficiaries, attempt to display the reduction of their potential future capacity to those authorities by higher dividend distribution. Therefore, the possibility of bargaining in legal payouts to government executive institutions and relevant organizations increases. As a consequence, owners of larger corporations expect receiving greater profit. Nevertheless, these results are not verified in the fourth hypothesis test such that there is no difference of the impact of firm size on dividend policy of MCs and DCs. The report of firm size's lack of significance for companies indicates that largeness of companies cannot be considered a merit for more dividend payout between the shareholders. This finding is in contrast with the results of Al-Malkawi (2007) and Rabaleh and Hernytid (2008).

Based on signaling theory, it is evident that those companies which possess a successful functional perspective have managers who, without concern for the lack of liquidity or uncontrollable increase of shareholders' expectations, attempt to distribute profits. As for expressing success in function, normally, the profitability criterion is utilized, the results obtained from the second and sixth hypotheses tests are in line with the verification of signaling theory. For the second hypothesis, this impact is such that the role of shareholders in MCs and DCs is not different from one another. These results are consistent with the results achieved by Ferris (2006). The impact of growth on dividend policy of MCs and DCs was reported as different so that there was a direct relationship between sales growth and dividend payout ratio of MCs, which is in line with the obtained results by Aivazian and Both (2003) and in contrast with the findings of Jones (2001). The positive impact of growth for domestic companies was relayed as lacking significance.

According to the transaction cost theory, it is deduced that companies should seek cheap financial sources for financing. Therefore, financing from outside the company and, especially, abroad contains costs of conclusion of contract and alternative relevant expenses, which would not make much difference, considering the sources of financing compared with its expenses. Therefore, the results obtained from the fifth hypothesis test, which was conducted in Tehran Stock Exchange companies, the transaction cost theory for MCs and DCs have occurred and approved, approximately, the same. Therefore, it can be claimed that, due to the increased risk of getting debt, dividend policy of companies has traveled the reverse direction and the tendency of companies to distribute profits has declined. This finding is consistent with the results by La Porta (2000), Ferris and others (2006) and AlMalkawi (2007).

According to agency cost and in line with the reduction of conflict of interests between owners and managers, cash distribution, so as to reduce the exercise of personal opinion of managers, has led to owners' approval. The owners of MCs and DCs active in Tehran Stock Exchange, rather than making the reduction of conflict of interests their own policy, have chosen the priority of keeping free cash flows available for managers in order to gain future benefits. Therefore, the results obtained from the third hypothesis test are justified based on the same hypothesis. The impact of free cash flows on dividend policy of MCs and DCs is reported as different such that free cash flows, as agency costs had negative and significant relationship with dividend policy of MCs and it does not appear that dividend payout is dependent on additional cash flows resulted from company's operations. This finding confirms results of studies by Aggarwal and Aung Kyaw (2010). Furthermore, this impact was reported as lacking significance for domestic companies. The table below displays summary of results.

Table 8 . Summary of results

\begin{tabular}{|c|c|c|}
\hline Main hypothesis & \multicolumn{2}{|c|}{ Results } \\
\hline There is a significant difference between dividend policy of multinational and domestic companies. & \multicolumn{2}{|c|}{ Confirmation } \\
\hline \multirow{2}{*}{ Subsidiary hypotheses } & \multicolumn{2}{|c|}{ Results } \\
\hline & DC & MC \\
\hline Hypothesis 1: The impact of systematic risk on dividend payout ratio is negative and significant. & $x$ & $x$ \\
\hline Hypothesis 2: The impact of profitability on dividend payout ratio is positive and significant. & $\checkmark$ & $\checkmark$ \\
\hline
\end{tabular}


Table 8 (cont.). Summary of results

\begin{tabular}{|c|c|c|}
\hline Main hypothesis & \multicolumn{2}{|c|}{ Results } \\
\hline There is a significant difference between dividend policy of multinational and domestic companies. & \multicolumn{2}{|c|}{ Confirmation } \\
\hline \multirow{2}{*}{ Subsidiary hypotheses } & \multicolumn{2}{|c|}{ Results } \\
\hline & DC & MC \\
\hline Hypothesis 3: The impact of free cash flows on dividend payout ratio is positive and significant. & $x$ & $\checkmark$ \\
\hline Hypothesis 4: The impact of firm size on dividend payout ratio is positive and significant. & $x$ & $x$ \\
\hline Hypothesis 5: The impact of financial leverage on dividend payout ratio is negative and significant. & $\checkmark$ & $\checkmark$ \\
\hline Hypothesis 6: The impact of sales growth on dividend payout ratio is significant. & $x$ & $\checkmark$ \\
\hline
\end{tabular}

\section{References}

1. Adedeji, A. (1998). Does the pecking order hypothesis explain the dividend payout ratios of firms in the UK? Journal of Business, Finance and Accounting, 25 (9\&10), pp. 1127-1155.

2. Agrawal, A. \& Jayaraman, N. (1994). The dividend policies of all-equityfirms: A direct test of the free cash flow theory, Managerial and Decision Economics, 15 (2), pp. 139-148.

3. Aharony, J. and Swary, I. (1980). Quarterly Dividend and Earnings Announcementsand Stockholders Returns: An Empirical Analysis, Journal of Finance, 35, pp. 1-12

4. Aivazian, V. and Both, L. (2003). Do emerging firms follow different dividend policies from US firms? Journal of Financial Research, 26 (3), pp. 371-387.

5. Al-Malkawi, H.N. (2007). Determinant of Corporate Dividend Policy in Jordan, Journal of Economic and Administrative Science, 23, pp. 44-71.

6. Baker, Malcolm and Wurgler, Jeffrey. (2004a). A catering theory of dividends, Journal of Finance, 59, pp. 1125-1165.

7. Black, F. (1976). The Dividend Puzle, Journal of Portfolio Management, 2, pp. 5-8.

8. Brav, A., Graham, J.R., Harvey, C.R., Michaely, R. (2005). Payout policy in the 21 st century, Journal of Financial Economics, 77, pp. 483-527.

9. Brennan, M. (1970). Taxes, Market Value and Corporate Financial Policy, National Tax Journal, 23, pp. 417-427.

10. DeAngelo and Masulis, R. (1980). Optimal Capital Structure Under Corporate and Personal Taxation, Journal of finance Economics, pp. 3-29.

11. DeAngelo, Harry, DeAngelo, Linda and Stulz, M. Rene (2006). Dividend policy and the Earned/contributed capital mix: A test of the lifecycle theory, Journal of Financial Economics, 81, pp. 227-254.

12. Dempsey, S. and Laber, G. (1992). Effects of Agency and Transaction Cost onDividend Payout Ratios: Further Evidence of the Agency-Transaction CostHypothesis, Journal of Financial Research, 15, pp. 317-321.

13. Denis, D.J., Osobov, I. (2008). Why do firms pay dividends? International evidence on the determinants of dividend policy, Journal of Financial Economics, 89, pp. 62-82.

14. Easterbrook, F. (1984). Two Agency Costs Explanations of Dividends, American Economic Review, 74, pp. 650-659.

15. Eije, H.E., Megginson, W. (2008). Dividends and share repurchases in the European Union, Journal of Financial Economics, 89, pp. 347-374

16. Faccio, M. and Lang, L. (2002). The Ultimate Ownership of Western European Corporations, Journal of Financial Economics, 65, pp. 365-395.

17. Fama, E. and French, K. (2001). Disappearing Dividends: Changing FirmCharacteristics or Lower Propensity to Pay? Journal of Financial Economics, 60, pp. 3-43.

18. Fenn, W. George and Liang, Nellie. (2001). Corporate payout policy and managerial incentives, Journal of Financial Economics, 60, pp. 45-72.

19. Ferris, S., Sen, N., Yui, H. (2006). God Save the Queen and her dividends: Corporate payouts inthe U.K., Journal of Business, 79, pp. 1149-1173.

20. Glen, J., Karmokolias, Y., Miller, R. and Shah, S. (1995). Dividend Policy and Behaviorin Emerging Markets, IFC Discussion Paper, 26. Available at: www.ifc.org.

21. Holder, M., Langrehr, F. and Hexter, J. (1998). Dividend Policy Determinants: An Investigation of the Influences of Stakeholder Theory, Financial Management, 27, pp. 73-82.

22. Izadi Nia, Naser and Alinaghian, Nasrin. (2011). Identifying the factors affecting dividend using Logit model, Journal of Financial Accounting Researches, 3 (1), pp. 21-38.

23. Jahankhani, Ali and Qorbani, Said. (2005). Identifying and explaining the determinants of dividend policy in Tehran Stock Exchange listed companies, Journal of Financial Research, 20, pp. 27-48.

24. Jensen, G.R., Solberg, D.P. \& Zorn, T.S. (1992). Simultaneous determination ofinsider ownership, debt, and dividend policies, Journal of Financialand Quantitative Analysis, 27 (2), pp. 247-263.

25. Jensen, M. (1986). Agency Costs of Free Cash Flow, Corporate Finance, and Takeovers, American Economic Review, 76, pp. 323-329.

26. Jensen, M.C. \& Meckling, W. (1976), The theory of the firm: Managerial behavior, agency costs and capital structure, Journal of Financial Economics, pp. 305-360.

27. Kurdistani, Gholamreza, Nasiri, Mahmoud and Rahimpoor, M. (2010). The theory of dividend payout, messaging 
and operating performance of companies subsequent to cash dividends, Journal of Financial Accounting Researches, 2 (1), pp. 63-76.

28. La Porta, R., Lopez-de-Silanes and Vishnay, R.W. (2000). Ahency Problem and Dividend Policy Around the World, Journal of Finance, pp. 1-33.

29. Li, W., Lie, E. (2006). Dividend changes and catering incentives, Journal of Financial Economics, 80, pp. $293-308$.

30. Lloyd, W.P., Jahara, J.S. Jr. (1985). Agency cost and dividend payout Ratio, Quaterly Journal of Business and Economics, 24, pp. 19-29.

31. Manos, R. (2002). Dividend Policy and Agency Theory: Evidence on Indian Firms. Working Paper, Institute for Development Policy and Management, Universityof Manchester

32. Mihir, A., Desai, C., Fritz Floy and Hames, R. Hines Jr. (2007). Dividend Policy inside the Multinational Firm, Financial Management, pp. 5-28.

33. Miller, M. and Modigliani, D. (1961). Dividend Policy, Growth, and the Valuation of Shares, Journal of Business, 34, pp. 411-433.

34. Mohd, M., Perry, L. and Rimbey, J. (1995). An Investigation of Dynamic Relationship Between Agency Theory and Dividend Policy, The Financial Review, 30, pp. 367-385.

35. Mollah, S., Keasey, K. and Short, H. (2002). The Influence of Agency Costs onDividend Policy in an Emerging Market: Evidence from the Dhaka Stock Exchange. Working Paper. Available at: www.bath.ac.uk.

36. Myers, S.C. (1977). Determinants of corporate borrowing, Journal of Financial Economics, 5, pp. 145-175.

37. Pandey, I. (2001). Corporate Dividend Policy and Behaviour: The Malaysian Experience. Working Paper, Indian Institute of Management.

38. Pourheydari, Omid, Mohammadi, Amir and Rahimi, Ali Reza. (2009). Investigation of the stability of dividend policy in listed companies on the Stock Exchange, Accounting Researches, 1, pp. 96-111.

39. Raj Aggarwal, NyoNyo, Aung Kyaw. (2010). Capital structure, dividend policy, and multinationality: Theory versus empirical evidence, International Review of Financial Analysis, pp. 140-150.

40. Ross, S.A. (1977). The determination of financial structure - The incentive signaling approach, Rand Journal of Economics, 8 (1), pp. 23-41.

41. Rozeff, M.S. (1982). Growth, beta, and agency costs as determinants of dividend payout ratios, Journal of Financial Research, pp. 249-259.

42. Saidi, Parviz. (2005). Financial theory. $1^{\text {st }}$ ed. Iran: Islamic Azad University of Gorgan.

43. Sawicki, J. (2005). An Investigation into the Dividend of Firms in East Asia. Working Paper, Nanyang Technological University, Singapor.

44. Vogt, S.C. (1994). The cash flow investment relationship: Evidence from U.S. manufacturing firms, Financial Management, 23, pp. 3-20. 